https://berumpun.ubb.ac.id/index.php/BRP

\title{
EMERGING THE SCO AS AN EFFECTIVE UNION IN ASIA: CHINA'S ROLE AND AMBITIONS
}

\author{
Enayatollah Yazdani ${ }^{1}$, Rizwan Hossain ${ }^{2}$ \\ ${ }^{1}$ Associate Professor of International Relations, Center for the Middle East Studies School of \\ International Studies Sun Yat-sen University Zhuhai Campus China \\ ${ }^{2}$ Scholar of International Relations Canberra, Australia
}

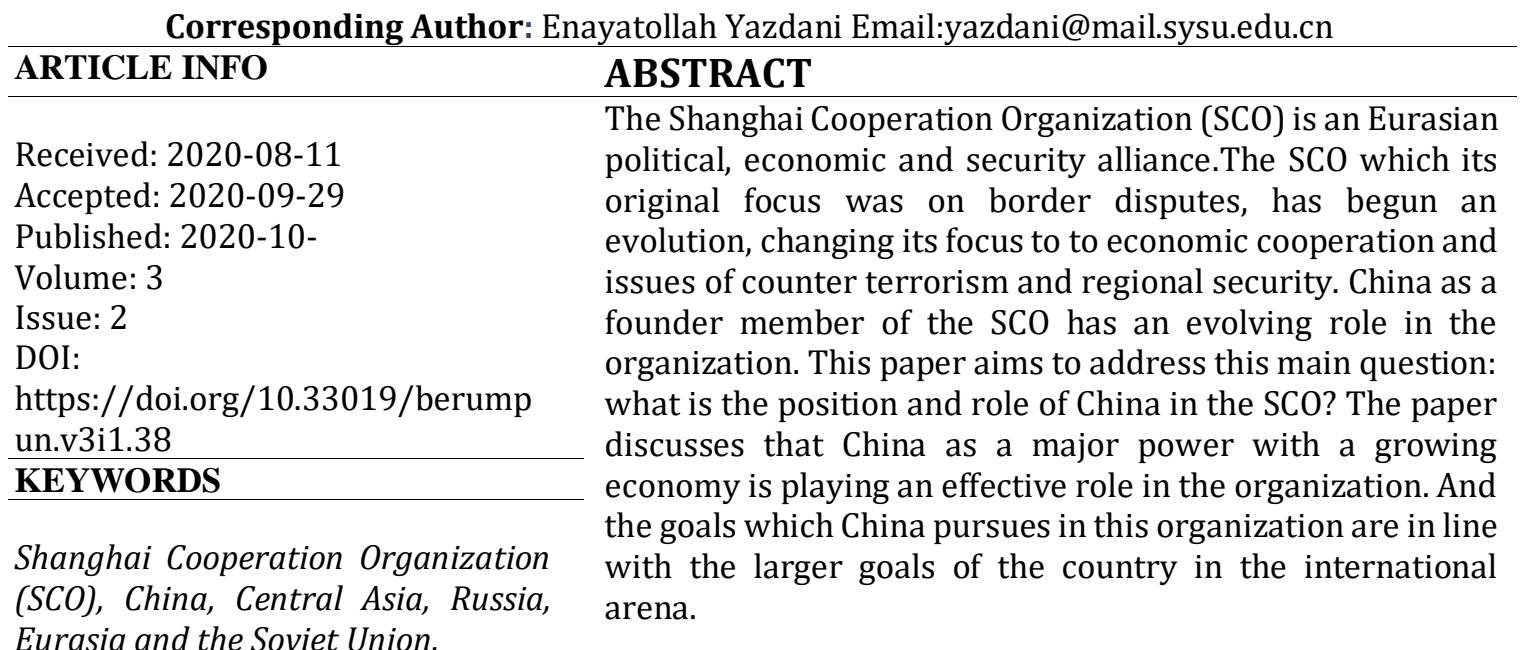

\section{INTRODUCTION}

The Shanghai Cooperation Organization, originally known as the Shanghai Five, was initially intended to resolve border issues between China, Russia and the Central Asian states following the collapse of the Soviet Union. However, from 2001 the forum appears to have begun a slow evolution, changing its focus from border demarcation to economic cooperation and issues of counter terrorism and regional security. Throughout the forum's history, Moscow and Beijing have attempted to use it to push their own regional and international agendas, making the SCO summits a good barometer of the two nations' bilateral relations as well as their respective international concerns.

For the first five years of its existence, the SCO was thought of as little more than a talking shop for central Asian leaders. Yet since its annual summits in 2005 and 2006 -- its members have been trying to decide if the organization is to become an important political entity. More importantly, the SCO has the potential to become an important political and security organization of the major states located in the vast Eurasian landmass. 
https://berumpun.ubb.ac.id/index.php/BRP

China as a founder member of the SCO has a evolving role in the organization. Beijing views the SCO as an important vehicle for developing of regional cooperation and "going global" as well. Accordingly, this paper aims to address this question: what is the position and role of China in the SCO? The paper attempts to explore the China's position and role in the organization, it also addresses China's ambitions in the SCO. In addition, it intents to analyse the prospects of the SCO as a viable regional organization in the post-Cold War era.

\section{THE SIGNIFICANT OF SHANGHAI COOPERATION ORGANIZATION}

The establishment of "Shanghai Five" in 1996, was an effective move on border issues between the Central Asian republics of Kazakhstan, Kyrgyzstan, Tajikistan, Russia and China, then when Uzbekistan joined them in 2001, it was renamed as "The Shanghai Cooperation Organization". The organization is a Eurasian political, economic and security alliance, consisting of China, Russia Kazakhstan, Kyrgyzstan, Tajikistan; and Uzbekistan. India and Pakistan gained accession in June 2017 and there are numerous observer states including the likes of Iran, Afghanistan, Belarus and Mongolia (see the bellow map) ${ }^{1}$. In terms of geographic area and population, it makes the organization one of the largest in the world, and one of the most powerful. By now, its members cover $60 \%$ of the Eurasian continent, the eight SCO members have a population of half of the world population, and a GDP of nearly $20 \%$ of the world total. (Shanghai Cooperation Organization, 2020) (see also table 1).

Map 1: the SCO map (Shanghai Cooperation Organization, 2020)

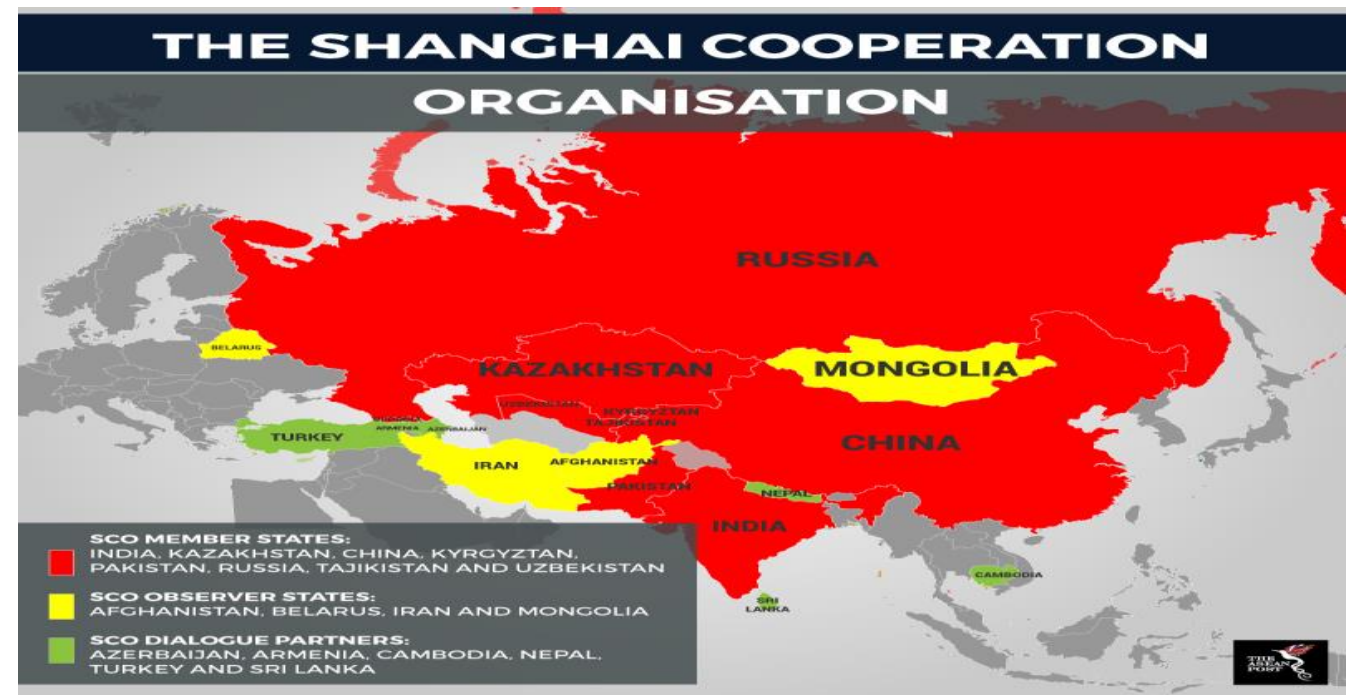

1 The SCO has also six dialogue partners, namely the Republic of Azerbaijan, the Republic of Armenia, the Kingdom of Cambodia, the Federal Democratic Republic of Nepal, the Republic of Turkey, and the Democratic Socialist Republic of Sri Lanka. 
https://berumpun.ubb.ac.id/index.php/BRP

Table 1: SCO members and observers' population 2020(World Population Review, 2020)

\begin{tabular}{ccccc}
\hline No. & Country & Statue & $\begin{array}{c}\text { Number of } \\
\text { Population }\end{array}$ & World Share \% \\
\hline 1 & China & Member & $1,439,464,621$ & 18.47 \\
\hline 2 & India & Member & $1,380,270,828$ & 17.70 \\
\hline 3 & Pakistan & Member & $220,955,441$ & 2.83 \\
\hline 4 & Russia & Member & $145,934,462$ & 1.87 \\
\hline 5 & Uzbekistan & Member & $33,477,578$ & 0.43 \\
\hline 6 & Kazakhstan & Member & $18,780,875$ & 0.24 \\
\hline 7 & Tajikistan & Member & $9,540,453$ & 0.12 \\
\hline 8 & Kyrgyzstan & Member & $6,525,942$ & 0.08 \\
\hline 9 & Iran & Observer & $83,992,949$ & 1.08 \\
\hline 10 & Afghanistan & Observer & $38,928,346$ & 0.50 \\
\hline 11 & Belarus & Observer & $9,449,323$ & 0.12 \\
\hline 12 & Mongolia & Observer & $3,278,290$ & 0.04 \\
\hline \multicolumn{7}{c}{ Total } & $\mathbf{3 9 0 , 7 7 5 , 8 1 7}$ & $\mathbf{4 3 . 4 8}$ \\
\hline & World & $\mathbf{7 / 8}$ billion & \\
\hline
\end{tabular}

Vladimir Norov (2019), SCO Secretary General, in regards with the important of the creation of the organization in an interview in September 2019 expressed that the rationale for establishing the Shanghai Cooperation Organization was based on radical changes in the system of international relations in the late 20th century. After the collapse of the Soviet Union in late 1991 and the end of the Cold War the world did not become any safer. Moreover, new threats and challenges emerged that acquired a global and unpredictable nature. It became evident that one or several countries cannot ensure security in the $21^{\text {st }}$ century. He asserted that it was in that troubled period when leaders of the SCO founding member countries displayed wisdom and vision by choosing a strategically correct path towards enhancing multilateral cooperation, and established the Shanghai Cooperation Organization.

By firmly upholding the "Shanghai Spirit", as the key principles of SCO cooperation stem, which embodies mutual trust, mutual benefit, equality, consultations, respect for the diversity of cultures and commitment to joint development, the SCO, indeed, has established a new model of international relations based on mutual respect, fairness and justice and win-win cooperation (Jing, 2018).

The SCO was originally conceived as a multifaceted structure with three levels of cooperation serving as its primary pillars. These include cooperation (1) in politics and security, (2) in trade and economic activity, and (3) in the development of cultural and humanitarian ties. The SCO sets as its ultimate goal the development and prosperity of the peoples living on its territory (Alimov, 2018: 114-124). 
https://berumpun.ubb.ac.id/index.php/BRP

Indeed, one of the most important achievements in Sino-Russian-Central Asian relations is the establishment of the Shanghai Cooperation Organization. The organization seems useful to all the parties involved, but for different reasons. Originally intended to resolve borders disputes between the member states and to prevent Russia or its predecessor the Soviet Union from dominating Central Asia (Alimov, 2018: 114-124). ${ }^{2}$ The SCO's focus has evolved slightly over time, but one of its main focus is battling the separatism, religious extremism, and terrorism. While anti-terrorism and emergency exercises have been held between SCO countries militaries its focus is on regional cooperation.China has conducted joint anti-terrorist military exercises, the first having united Kyrgyz and Chinese armed forces in 2002 ("Exercise-01"). A joint Chinese-Tajik exercise took place in 2006 ("Coordination2006"). The same type of exercises has been organized with the participation of Kazakhstan ("Tianshan I") in 2006, and with Tajikistan and Kyrgyzstan ("Tianshan II") in 2011(Bolonina, 2019:6).

The SCO's focus has shifted in recent years to economic concerns, and in 2015 they released a 10-year development strategy in which economics was featured prominently and where a provision for developing common approaches of the SCO member states to the Chinese Belt and Road Initiative (BRI) (Sutter, 2016: 385-386). Indeed, the SCO - and its predecessor, the Shanghai Five mechanism-started as a low profile organization which focused on building trust and solving security issues but has gradually grown into a serious regional organization which aims at mutually beneficial cooperation in the fields of politics, security, the economy, trade, culture and energy.

In fact, one can argue that the SCO is a multi-dimensional organization which can improve Chinese ties with the five Central Asian republics in economy, trade, and security as well (Yazdani and Toiserkani, 2007:33-36). As for security the SCO has pursued counter-terrorist strategy particularly after the events of 9/11, 2001. To this, the SCO has created the Regional Anti-terrorist structure (RATS), based in Tashkent, Uzbekistan Capital, with an objective to collect, analyses and share relevant information, to create databases of terrorist networks and to maintain connections with other security organizations(Bolonina, 2019:6, Jin and Dehang, 2019:67-74 ).

\footnotetext{
${ }^{2}$ At a summit meeting on June 14, 2001, the leaders of China, Russia together with four Central Asian republics, Kazakhstan, Kyrgyzstan, Tajikistan and Uzbekistan, met to sign the Declaration on the Establishment of the SCO in Shanghai, China. The SCO has declared aims to 'create a new international political and economic order featuring democracy, justness and rationality and facilitate cooperation in economy and trade, science and technology, culture, education, energy, transportation and environmental protection among the member states.' The Organization has also focused on security and terrorism issues (Saksena, 2014).
} 
https://berumpun.ubb.ac.id/index.php/BRP

In the two decades of its evolution, the SCO has emerged as an excellent multilateral mechanism for regional security, economic cooperation, cultural integration and transnational connectivity. The presence of the four nuclear states, China, Russia, India and Pakistan in the Shanghai Organization Cooperation gives the organization nuclear power potential. It can increase its power worldwide. In fact, with joining India and Pakistan and if Iran would join the organization as permanent member, the SCO can be regarded as an "Nuclear OPEC" consist of the world's large oil and gas reserves with a nuclear capability.

\section{REACTION OF THE SCO TO US GLOBAL AND REGIONAL INFLUENCE}

For all the bluster at the SCO summits, this regional multilateral grouping SCO is not inherently opposed to the US at present. SCO summits have reflected a very pragmatic and non-confrontational approach to growing US/Western European hegemony in international affairs. US analysts' alarmist opinions that SCO has the potential to become an oriental NATO or an anti-western alliance are premature and misleading. To date SCO has been unable to devise any coherent military or security cooperation strategy apart from developing und erstanding amongst member states on issues such as border disputes, counter-terrorism, economic cooperation and energy exploitation. In fact, the SCO in its present composition can be compared to ASEAN ${ }^{3}$ Regional Forum (ARF), which addresses security issues in Southeast Asia. Like the ASEAN regional Forum, most SCO members address most security related issues on a bilateral basis. Hence, SCO cannot be compared to NATO or other Western security organization that were developed for specific purposes and eventually developed into a coherent and effective security alliance system (Weitz 2018).NATO's specific task was to contain Soviet communism, which it effectively did from 1949 to 1991 whereas SCO is based on vague notions of multilateral regional cooperation among states that have divergent political and economic goals.

However, some have speculated that China and Russia have larger plans for the modern SCO. Specifically, to counter "U.S. policies of economic penetration of the oilrich Caspian Basin and to facilitate a global balance of power through a multi-polar order that would frustrate U.S. hegemonic goals."(Bhatty, 2000).However, the 2005 summit produced one highly publicized communiqué. This SCO communiqué called for the United States to establish a timetable for the redeployment of its forces from Uzbekistan (Khanabad base) and Kyrgyzstan (Manas base). The SCO justification was reportedly based on the U.S. led anti-terrorism coalition's completion of the active military phase of operations in Afghanistan (Jefferson E. and USAF, 2005). Indeed, the 2005 declaration by the Shanghai Cooperation Organization for the U.S. to vacate bases in Central Asia was a boost for Beijing and Moscow, both of whom have bristled

${ }^{3}$ The Association of Southeast Asian Nations (ASEAN).

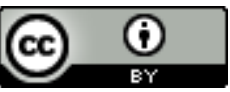


https://berumpun.ubb.ac.id/index.php/BRP

at the growing influence of the U.S. in the region (Goodenoug, 2005). The U.S. has maintained bases in Uzbekistan and Kyrgyzstan since late 2001, in support of the anti-terror operation launched in nearby Afghanistan after the 9/11 events. Furthermore, the inclusion of Iran as an observer member in the SCO has raised speculation in Washington that this forum may be developing into an anti-US alliance. However, such speculations are premature as observer states are only 'dialogue partners'. Yet, even though the SCO has no focus on external threats, "Russia finds a common interest with China in keeping the expansive United States and NATO out of the area by means of the SCO" (Oldberg, 2007:25)

Nevertheless, the major anti-American stance of the SCO can be understood from the final declaration of the 2006 summit in Shanghai: "The SCO will make a constructive contribution to the establishment of a new global security architecture of mutual trust, mutual benefit, equality and mutual respect," the declaration asserted: "Threats and challenges can be effectively met only when there is broad cooperation among all countries and international organizations concerned. What specific means and mechanisms should be adopted to safeguard security of the region is the right and responsibility of countries in the region." The statement went on to indicate that "Central Asian countries must choose development paths based on their needs and interest ."Diversity of civilization and the model of development must be respected and upheld. Differences in cultural traditions, political and social systems, values and model of development formed in the course of history should not be taken as pretexts to interfere in other countries' internal affairs. "Model of social development shod not be exported. "(Weitz, 2006).

\section{THE DEVELOPMENT OF THE SCO AND CHINA'S ROLE}

China's role in the creation and evolution of the SCO is one of the most significant foreign policy initiatives to emanate from that country in the last more than two decades. In essence, the SCO is becoming an instrument for the Chinese approach to international affairs, which currently involves a policy of accommodating Western interests in Asia while at the same time increasing Chinese influence in selected parts of Asia. The SCO summits final declarations have included favoured Chinese formulations such as opposition to "exporting models of social development" and an emphasis on combating not just terrorism and extremism but also separatism. Even the SCO summit in June 2006 reflected this Chinese approach to foreign relations. SCO member countries signed ten documents on information security, anti-terrorism, economic and financial cooperation at the summit meeting in 2006. The documents included a declaration on the fifth anniversary of the SCO founding, a statement on international information security, a resolution on SCO secretary-general and

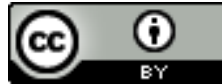


https://berumpun.ubb.ac.id/index.php/BRP

another on the secretariat, a resolution on fighting terrorism, separatism and extremism from 2007 to 2009, an agreement on joint anti-terrorism actions among member countries, and an agreement on cutting off the infiltration channels of terrorists, separatists and extremists.

Another factor that pushed China to give the SCO the formal trapping of regional organization was largely related to its security strategy to prevent Uighur separatists from using Central Asian states as a base for separatist activities in Xinjiang. The joint fight by SCO states against terrorism and threats to national sovereignty has won China assurances from Muslim Central Asian states that they would not provide assistance to their religious and ethnic brethren engaged in militant separatist activities in Xinjiang. Thus, Beijing's commitment to regional security through the SCO to fight separatism and terrorism.

The SCO is an emerging regional organization in Central Asia, but during its short history, it has largely remained an enigma. It has been characterized as a security organization, a regional forum, and an anti-terrorism coalition. Another common characterization of the SCO is as a Russian and Chinese led alliance created to counter U.S. hegemony. These explanations of the SCO have their shortfalls and provide little insight of the primary motivations and interests driving the SCO's evolution. The SCO, as regional security architecture, can be seen as a logical follow up to the 1990 agreement between the former Soviet Union and China. Their goal was to ensure good neighbourly ties, as well as to reduce the number of armed forces in the border regions of Central Asia. The independence of the Central Asian Republics in 1991 brought new sovereign nations into the regional discussions. The original Shanghai Agreement developed from two delegations; one group led by Russia representing the Commonwealth of Independent States (CIS), while the other group was Chinese. The 1996 meeting in Shanghai and the 1997 meeting in Moscow laid the foundation of the modern SCO. Originally, the Shanghai Forum was formed to address a number of regional issues in Central Asia. First, the Shanghai Forum was committed to fostering friendly relations and cooperation between its member states. Second, they wanted to promote mutual military trust between their countries. Finally, they wanted to reduce the number of armaments along the borders of their countries making it a 100-km demilitarised zone (Jefferson and USAF, 2005).

The 1998 meeting of China, Kazakhstan, Kyrgyzstan, Russia and Tajikistan in Almaty, Kazakhstan marked a dramatic departure from previous conferences where things were said, but never done. The vision for the meeting was to lay the foundation "to turn the border between the five countries into a frontier of genuinely equitable and mutually advantageous cooperation."(Akimov, 1998) Before the meeting one observer noted, "The five countries will come out as independent partners in the negotiations alliance."(Akimov, 1998) The meeting of the Group of Five was 
https://berumpun.ubb.ac.id/index.php/BRP

attended by the president of each country, with the exception of Russia, which was represented by Foreign Minister Primakov instead of President Yeltsin. ${ }^{4}$ The primary purpose of the meeting was to signify the joint statements of the 1996 and 1997 meetings, including resolving Soviet era border security legacy issues and to make the organization "weightier and more solid."(Akimov, 1998) During the Cold War, Central Asia held a great concentration of opposing Soviet Union and Chinese forces. However, in the new conditions the countries of the region have resolved to turn what was once the major zone of tension into a zone of security (Jefferson and USAF, 2005). The five countries also took a "principled position on the nuclear tests carried out by India and Pakistan."(Jefferson and USAF, 2005) This unanimity demonstrated the SCO's concern over issues which could lead to regional instability and "reflects their confidence and determination in nuclear non-proliferation and prevention of nuclear tests." (Jefferson and USAF, 2005) In addition, the Chinese took the opportunity at this gathering to meet specifically with Kazakhstan to resolve border dispute issues between their countries. In essence, the SCO provided the perfect multilateral platform for China to improve regional stability through this reduction of border forces and presents that the SCO is an effective tool for China to accomplish such a result (Battams-Scott, 2019).

The 1999 Shanghai Five meeting in Bishkek was significant in that the members began to talk about reviving the "silk road" economy. The new "silk road" involves the economic integration of the Central Asian Republics, Russia, and China through trade and investment, especially in the energy sectors. However, China was already busy mapping out its plans for the SCO prior to September 11, 2001.Chinese President Jiang Zemin called on the member nations to continue their cooperation "to guarantee regional security, crack down on the forces of religious extremism and ethnic separatism, as well as combating international terrorist activities."(Bhatty, 2000) Additionally, the post conference joint communiqué urged SCO members to develop further cooperation between ministries of defence and interior(Jefferson and USAF, 2005).

A review of the SCO's summit declarations and activities, in fact, indicate that China perceives the organization as a blank canvas to hone its own approaches to leading on the international stage. Chinese official newspapers and academics have described the organization as a forum for China to explore and implement a new model of international relations. Moreover, official releases from the SCO itself acknowledge the need for the group to continue refining coordination and organization mechanisms, indicating that China's strategy for engaging the organization is evolving

${ }^{4}$ It was unclear why President Yeltsin did not attend the conference. Several theories are that he did not attend due to a dispute with Kazakhstan's President Nazarbayev over allocation of Caspian Sea resources or, more logically, due to internal Russia political tensions. Regardless, the Beijing reaction was reported as not positive. 
https://berumpun.ubb.ac.id/index.php/BRP

as the SCO's issue set expands in scope (Grace 2018). Therefore, on can argue that, the current value of the SCO is as a forum for Beijing to define and articulate its interests, shape the focus of international institutions based on its own domestic priorities, lobby its neighbors to adopt its approach, and codify those views within an internationally legitimate multilateral process.

Indeed, China's initial step into the Shanghai Cooperation Organization was driven by a strategic necessity stemming from the collapse of the Soviet Union and the need for clear territorial boundaries, rather than a broader plan to imbue Eurasia with multilateralism. In its early stages, the SCO remained primarily focused on counterterrorism activities. The intense focus on this issue set was motivated by China's need to elicit cooperation from Central Asian states in its campaign to stem Uyghur separatism. The SCO 2018 summit in Qingdao, a Chinese city, included references to issues as diverse as infectious diseases, e-trade, Afghanistan's peace process, the Syrian Civil War, international trade barriers, peace on the Korean Peninsula, disarmament and nonproliferation, state sovereignty, counterterrorism, drug-trafficking, anti-corruption efforts, and a host of other topics (Shanghai Cooperation Organization, 2018).

As the founding member of SCO, China is willing to, together with all parties, promote the building of community of shared future, a common home of security, stability, development and prosperity. As Abigail C. Grace (2018) has analyzed in the years to come, it remains to be seen China itself will adhere to the Shanghai Cooperation Organization's pledge to advance a "new type of international relations" defined by equality among all states and domestic political non-interference. At the SCO Astana Summit June 2017, President Xi Jinping reached important consensus with all parties on consolidating solidarity and mutual trust, strengthening security cooperation, docking development strategies, deepening people-to-people and cultural exchanges and other aspects (Jing 2018).

One important task of China role in the SCO is the country's Belt and Road Initiative. It .presents how effective the SCO is as a tool due to the multilateral platform BRI is a multilateral proposal to upgrade infrastructure, improve China's bilateral ties, and“ "international institutions, as well as drive much needed global development (Feldshuh, 2018). There has been an "SCO agreement on international road ,transportation facilitation and an infrastructure network covering roads, railways energy and telecommunications" all to progress theBRI Liangyu, 2018)) .Indeed, a key deliverable for the 2018 SCO Summit was the "strengthening of ties" between the SCO countries and the Belt and Road Initiative, which, "have been closely related from the very beginning" (Grace, 2018). 
https://berumpun.ubb.ac.id/index.php/BRP

On top of BRIChina has also offered the SCO , member stateslarge loans at lowinterest rates with which they can spend freely within their country In fact, with the introduction of the Belt and Road Initiative, China was able to build on the framework of bilateral engagement with individual SCO member states to shape the group's receptiveness towards Chinese investment. In 2004, "China offered USD million 900 in credit at preferential rates to the other five members of the SCO" (Chung, 2006: .(11 With the level of trade increasing - "in the first quarter of 2018, trade volume ,between China and other SCO members jumped 20.7 percent year on year" (Liangyu and China's economy is soon poised to take the world number one spot, it - (2018 shows how the SCO has been highly effective forBeijing in the implementation of Belt and Road Initiative and regional economic development. As table 2 shows three of six BRI corridors are passing through the SCO members.

Table 2: China's BRI Corridors (Business Reporting Desk, 2020)

\begin{tabular}{|c|c|c|c|c|}
\hline No. & Corridor & Connection & Purpose & Countries \\
\hline 1 & $\begin{array}{l}\text { New Eurasia } \\
\text { Land Bridge }\end{array}$ & Rail to Europe & $\begin{array}{c}\text { Trade and } \\
\text { commercial }\end{array}$ & $\begin{array}{l}\text { Kazakhstan, } \\
\text { Russia, Belarus, } \\
\text { and Poland }\end{array}$ \\
\hline 2 & $\begin{array}{c}\text { China, Mongolia, } \\
\text { Russia Economic } \\
\text { Corridor }\end{array}$ & $\begin{array}{l}\text { rail links and the } \\
\text { steppe road- } \\
\text { this will link with } \\
\text { the land bridge }\end{array}$ & $\begin{array}{c}\text { Trade and } \\
\text { commercial }\end{array}$ & $\begin{array}{c}\text { China, Mongolia } \\
\text { and Russia }\end{array}$ \\
\hline 3 & $\begin{array}{l}\text { China, Central } \\
\text { Asia, West Asia } \\
\text { Economic } \\
\text { Corridor }\end{array}$ & Rail & $\begin{array}{c}\text { Trade and } \\
\text { commercial }\end{array}$ & $\begin{array}{c}\text { Kazakhstan, } \\
\text { Kyrgyztan, } \\
\text { Tajikistan, } \\
\text { Uzbekistan, } \\
\text { Turkmenistan, } \\
\text { Iran, and Turkey }\end{array}$ \\
\hline 4 & $\begin{array}{c}\text { China Indochina } \\
\text { Peninsula } \\
\text { Economic } \\
\text { Corridor }\end{array}$ & & $\begin{array}{l}\text { Trade and } \\
\text { commercial }\end{array}$ & $\begin{array}{c}\text { Viet Nam, } \\
\text { Thailand, Lao } \\
\text { People's } \\
\text { Democratic } \\
\text { Republic, } \\
\text { Cambodia, } \\
\text { Myanmar, and } \\
\text { Malaysia }\end{array}$ \\
\hline 5 & $\begin{array}{c}\text { China, Pakistan } \\
\text { Economic } \\
\text { Corridor }\end{array}$ & Water port & $\begin{array}{c}\text { commercial and } \\
\text { military }\end{array}$ & $\begin{array}{c}\text { Links Kashgar } \\
\text { city (free } \\
\text { economic zone) } \\
\text { in landlocked } \\
\text { Xinjiang with the } \\
\text { Pakistan port of } \\
\text { Gwadar } \\
\end{array}$ \\
\hline 6 & $\begin{array}{c}\text { China, } \\
\text { Bangladesh, } \\
\text { India, Myanmar } \\
\text { Economic } \\
\end{array}$ & & $\begin{array}{l}\text { commercial and } \\
\text { security }\end{array}$ & $\begin{array}{c}\text { China, } \\
\text { Bangladesh, } \\
\text { India, and } \\
\text { Myanmar }\end{array}$ \\
\hline
\end{tabular}


https://berumpun.ubb.ac.id/index.php/BRP

Corridor

According to Chinese ambassador to Pakistan, Yao Jing (2018), in general, China has put forward the following proposals as five pillars of cooperation in the framework of the SCO:

1-Consolidate solidarity and coordination. China thinks that all member states should deepen political mutual trust, increase mutual support, enhance exchanges and cooperation between legislative bodies, political parties and in the judicial fields, and build a community of shared future featuring equal treatment, mutual support, and sharing of weal and woe as well as safety and danger. The Chinese side proposes to draw up a 5-year outline for the implementation of the Treaty on Long-term Good Neighbourliness, Friendship and Cooperation of the SCO Member States.

2- Jointly tackle challenges. SCO members are all facing security challenges. China supports the implementation of the SCO Convention on Combating Extremism, advocates strengthening the building of regional counter-terrorism institutions, and proposes to hold a defence security forum and formulate a three-year program of cooperation to combat the "three forces".

As peace and reconciliation in Afghanistan is imperative to the peace and security of the region, China calls upon all parties to support it, and expects the SCO-Afghanistan Contact Group to play a more active role in it. We also should strengthen the mechanism construction of law enforcement and security cooperation, and enhance cooperation in combating drugs and cross-border crimes.

3-Deepen practical cooperation. China and relevant parties are actively advancing the integration between the "Belt and Road" construction and regional cooperation initiatives as the construction of Eurasian Economic Union and other national development strategies like the "Bright Road" of Kazakhstan.

Yao Jing (2018) stated that it is China's suggestion to gradually put in place institutional arrangements for regional economic cooperation, and we may begin with a SCO trade facilitation agreement. For greater connectivity between regional countries, China supports the opening of the cross-border routes on schedule as prescribed in the Agreement between the Governments of the Member States of the Shanghai Cooperation Organization on Creating Favourable Conditions for International Road Transportation. China welcomes non-SCO countries in our region to join the Agreement, and endorses the formulation of a plan for coordinated development of roads among SCO member states. He added to mobilize more resources and driving force for practical cooperation under the SCO framework, China supports the establishment of a mechanism for sub-national cooperation and 
https://berumpun.ubb.ac.id/index.php/BRP

has vigorously promoted SME cooperation by its initiatives of economic think-tanks alliance and e-commerce alliance of the SCO. China suggests that we fully utilize the existing platforms to raise finance for SCO projects, while at the same time exploring at the expert level possible ways to establish the SCO development bank. China also encourages financial institutions such as the Asian Infrastructure Investment Bank, the Silk Road Fund and the SCO Interbank Consortium to provide more financing support for connectivity projects.

In case of trade between China and the SCO member states, China's trade volume with these countries stood at USD 337 billion in 2018, a rise of USD 47 billion since 2013, with Russia and India emerging as Beijing's biggest trading partners within the Eurasian bloc. Beijing's total exports to SCO countries increased by more than USD 35 billion in the past five years - from USD 177 billion in 2013 to USD 212 billion in 2018; while China's imports from these countries went up by USD 12 billion - from USD 113 billion to USD 125 billion - during the same period (Bhaya, 2019) . ${ }^{5}$ In addition, China has invested huge amount of revenue in the Central Asian countries (see also the bellow figure).

\section{Figure: China Investment in the SCO members and Turkmenistan in Central Asia for 10 years 2004-20146}

\section{China's Stock of Outward Direct Investment to Central Asia}

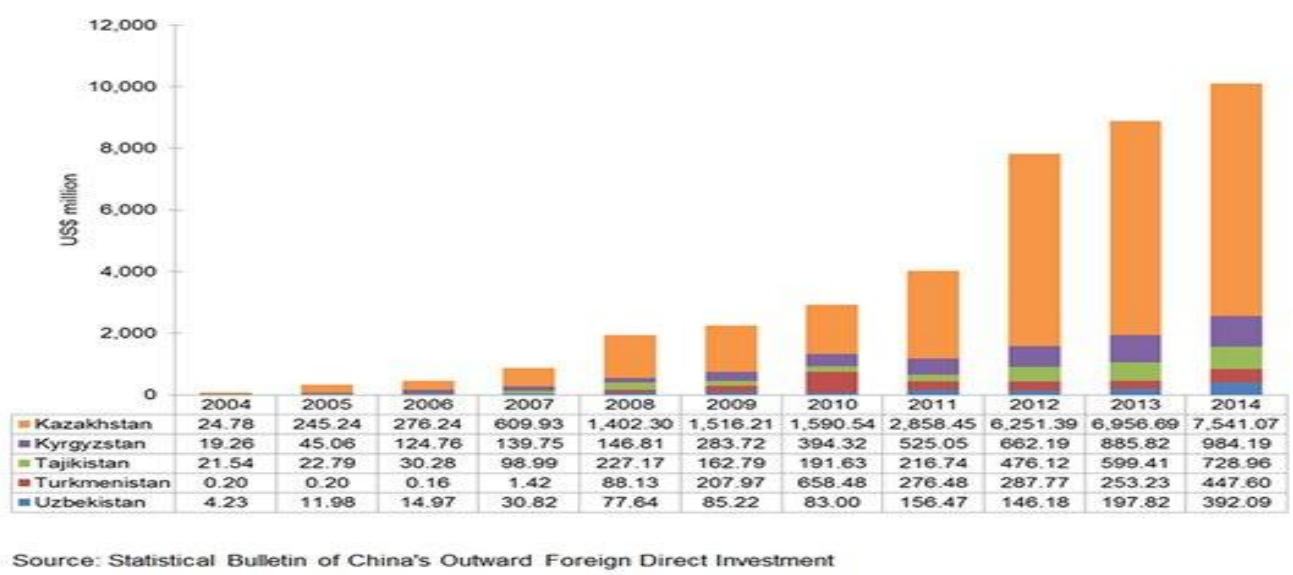

${ }^{5}$ Surprisingly, the United States remained China's biggest trading partner in 2018 with the total trade volume of almost 600 billion U.S. dollars, nearly double the China-SCO trade figures (Bhaya, 2019).

${ }^{6} \mathrm{http} / / /$ www.hktdc.com/resources/MI_Portal/Article/rp/2015/11/472180/1447841101389_472180CentralAs ianMarkets5e_472180.jpg[accessed 26/07/2020]

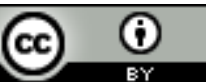


https://berumpun.ubb.ac.id/index.php/BRP

4- Enhance people-to-people and cultural bonds. We should build the SCO "family consciousness" and continue strengthening exchanges and cooperation in such areas as education, science and technology, culture, health care, environmental protection, sports, tourism, youth and locality. China is willing to, together with all parties, continuously well operate the SCO University, and well hold the youth exchange camp and the summer camp for primary and middle-school students. China will host SCO cultural and art festival events, and launch a "China-SCO cooperation program in human resources development". China also suggests setting up a mechanism for media cooperation, and would like to host the first SCO media summit.Beijing has also established number of Confucius Institutes across the SCO countries to promote Chinese language and culture(see the table 3).

Table 3: Number of Confucius Institutes in the SCO member states in Central Asia (Vakulchuk And Overland, 2019:118)

\begin{tabular}{cc}
\hline Country & No. \\
\hline Kazakhstan & 4 \\
\hline Kyrgyzstan & 3 \\
\hline Tajikistan & 2 \\
\hline Uzbekistan & 2 \\
\hline Total & 11 \\
\hline
\end{tabular}

In addition, in the tourism sect,tourism plays also a significant role in the economic development of SCO member states, which helps boost cultural exchanges and bolsters their continuously deepening communication. To this, there is growing number of Chinese tourists who are spending holidays in other member countries of the Shanghai Cooperation Organization, with Russia the leading destination. Chinese people's outbound trips to other SCO countries increased by double digits in 2017 and 2018, with over 2 million Chinese visitors for each year (Yamie 2019).

5- Uphold openness and inclusiveness. Openness has been a defining feature of the SCO since its inception. China supports the SCO in carrying out cooperation of various forms and in a broad range of areas with its observer states and dialogue partners as well as other countries, and in further reviewing the applications from the related countries for legal status in the SCO in accordance with its regulations and the principle of consensus. China stands for more exchanges and cooperation between the SCO and the United Nations and other international and regional organizations, in a joint effort to promote lasting peace and shared prosperity in the world (Jing 2018).

In fact, as Gao Fei (2010) has mentioned, by initiating and developing the SCO, China shows that it is shifting from a challenger of the international system to a responsible major power; from being bilaterally oriented to embracing multi-lateral relations; and from a 'communist ideology'-oriented nation to an economically and culturally- 
https://berumpun.ubb.ac.id/index.php/BRP

oriented country. On the other hand, China's leadership role in the SCO is important as China's GDP surpasses the combined total of all the other members, offering immense opportunities for member states to benefit at bilateral and multilateral levels.

\section{CHINA'S AMBITIONS IN SHANGHAI COOPERATION ORGANIZATION}

One of the most prominent features of China's foreign policy behavior in recent years is its increasing activism in multilateral diplomacy. From the UN to the WTO, from the ASEAN Regional Forum (ARF) to the six-party talks, from the Boao Forum to the Shanghai Cooperation Organization. In particular, China's usage of the Shanghai CooperationOrganization has resulted in many of its foreign policy ends being reached or at least had significant progress towards them. Regional security was once at the forefront of the Chinese policy agenda, but through border forces reductions, focus on nonconventional threats such as terrorism, and the removal of external actors that may disrupt the political status quo, regional stability has improve(Battams-Scott, 2019).

Generally, China's regional foreign policy, is based on four main pillars:

a- Participate in regional organizations.

b- Expanding strategic cooperation and deepening bilateral relations with regional powers.

c- Expanding regional economic relations.

d- Reducing distrust and concern in the regional security environment (HUI, 2019).

Accordingly, in the framework of these pillars China has involved in the SCO very actively. The main Chinese motivations in the SCO are:

\section{5-1. Stability in a security environment}

Forming a Shanghai Cooperation Organization and strengthening it in two ways has helped to produce and maintain stability in China's security environment. One is that regional governments, especially in the Central Asian countries that have longstanding ethnic and religious ties to the people of Xinjiang, have warned against escalating the Xinjiang crisis.

On the other hand, according to the charter of the Shanghai Cooperation Organization, countering separatism, extremism and terrorism as "three evils" is one of the main goals of this organization. In this regards, SCO Secretary General, Vladimir Norov, has proclaimed that: "three months prior to the tragic 9/11 events in New York [and 
https://berumpun.ubb.ac.id/index.php/BRP

Washington] in 2001, the Convention on Combating Terrorism, Separatism and Extremism was signed within the SCO, a document which served as evidence of the organization's readiness to aggressively fight these "three maligned forces"" (Norov, 2019). All three of these factors are contributing to the Xinjiang crisis. On the one hand, the rebels of Xinjiang are seeking independence from China. In addition, the Chinese government considers them extremist, and most importantly, the separatists of Xinjiang have links to insurgent forces in Afghanistan and Pakistan. It is natural that if China can use this organization to consolidate the capacity of the countries in the region to deal with these three effective forces in the crisis of Xinjiang, which has deep international roots, it has taken steps to strengthen stability in its security environment. That is why stability in Central Asia is crucial to China in terms of its strategic position. Central Asia is part of China's security environment, and it is natural that dominating the region, especially by the United States, would be a longterm threat to the country.

The growing U.S. presence and influence in the region, especially after the events of Spetember11, 2001 and the occupation of Afghanistan, has become a security concern for China. This has led China to pursue more serious institutional cooperation with neighboring countries in the framework of the Shanghai Cooperation Organization to balance Russia's growing influence with the United States. Of course, this does not mean that the interests of China and Russia are completely at odds with those of the United States in the region, but that the balance of the historical logic of relations between the great powers is balanced. Based on this, one of the goals of China in overcoming and strengthening the Shanghai Cooperation Organization can be considered as creating and strengthening stability in the security environment.

\section{5-2. Attract international development resources}

In recent years, China has always had the highest growth and development rates in the world. It is natural that advancing at such a rate will first increase the need for resources, especially primary resources, and secondly the need for foreign markets. From this point of view, Central Asia is of great importance for China in the field of primary resources, especially energy. China's economic growth in recent years has sharply increased its energy needs; it has made it the second largest consumer of oil in the world after the United States.

Indeed, China's growing energy requirements give it a significant interest in getting access to the energy resources of Central Asia and the Caspian Basin as well (Liao, 2019,Huirong and Hongwei, 2012). As the table 4 shows, at present China is the world's largest consumer of energy. Accordingly, Chinese majors like CNPC, Sinopec and CNOOC are highly interested in the Central Asian oil and gas deposits and they have contributed largely in the construction of gas and oil pipelines connecting 
https://berumpun.ubb.ac.id/index.php/BRP

Kazakhstan and Turkmenistan,which are today the biggest regional exporters of oil and natural gas respectively, to Chinese territory ( Bolonina, 2019:6).

Table 4: The world 15 Top Crude Oil Importing Countries in 2019(Workman, 2020)

\begin{tabular}{|c|c|c|c|}
\hline Rank & Importer & $\begin{array}{c}\text { Crude Oil Imports } \\
\text { (US\$) }\end{array}$ & $\begin{array}{c}\text { \%World } \\
\text { Total }\end{array}$ \\
\hline 1 & China & $\$ 238,707,061,000$ & $22.6 \%$ \\
\hline 2 & $\begin{array}{l}\text { United } \\
\text { States }\end{array}$ & $\$ 132,370,663,000$ & $12.5 \%$ \\
\hline 3 & India & $\$ 102,306,491,000$ & $9.7 \%$ \\
\hline 4 & Japan & $\$ 73,085,389,000$ & $6.9 \%$ \\
\hline 5 & $\begin{array}{l}\text { South } \\
\text { Korea }\end{array}$ & $\$ 70,193,489,000$ & $6.6 \%$ \\
\hline 6 & $\begin{array}{c}\text { Netherland } \\
\text { s }\end{array}$ & $\$ 46,414,486,000$ & $4.4 \%$ \\
\hline 7 & Germany & $\$ 40,737,628,000$ & $3.9 \%$ \\
\hline 8 & Spain & $\$ 30,499,660,000$ & $2.9 \%$ \\
\hline 9 & Italy & $\$ 29,615,998,000$ & $2.8 \%$ \\
\hline 10 & $\begin{array}{l}\text { United } \\
\text { Kingdom }\end{array}$ & $\$ 24,542,383,000$ & $2.3 \%$ \\
\hline 11 & France & $\$ 24,446,306,000$ & $2.3 \%$ \\
\hline 12 & Singapore & $\$ 24,224,539,000$ & $2.3 \%$ \\
\hline 13 & Thailand & $\$ 22,284,239,000$ & $2.1 \%$ \\
\hline 14 & Taiwan & $\$ 21,326,199,000$ & $2 \%$ \\
\hline 15 & Belgium & $\$ 18,784,563,000$ & $1.8 \%$ \\
\hline
\end{tabular}

Central Asia has significant oil and gas resources; therefore, China is trying to influence the energy resources of this region as much as possible. Central Asia's energy resources also benefit China's neighborhood, such as Japan. This advantage is important because China has always been concerned about energy security, as it is largely maritime and controlled by the United States Navy, and it goes without saying that the United States can use this control as a lever in times of need, applying pressure on China. But Central Asia's oil and gas pipeline routes to China are by land and have little control. Therefore, China has quickly entered the energy market of this 
https://berumpun.ubb.ac.id/index.php/BRP

region and has been able to gain a significant share of it. Two main pipelines from Central Asia to China, the Central Asia-China gas pipeline and Kazakhstan-China oil pipeline, are already in operation (see the map 4). The Central Asia-China gas pipeline goes from Turkmenistan to Xinjiang in west of China. By connecting the republic of Turkmenistan to China's domestic grid, this pipeline makes it possible to transport gas some $7000 \mathrm{~km}$ from Central Asia to Shanghai. According to the PetroChina West Pipeline Company, as of December 31, 2019, 294.6 billion cubic meters of natural gas had been imported via the China-Central Asia gas pipeline, benefiting over 500 million people in 27 provinces of China (Yamei, 2020). The Kazakhstan-China pipeline running $988 \mathrm{~km}$ from Atasu in Kazakhstan to Alashankou at the Chin's border, was completed at the end of 2005 and began operating in May 2006, with a total investment of USD 700 million (see the map 2) (BBC Monitoring Energy, 2006).

\section{Map 2:SCO members' oil and gas pipelines to China7}

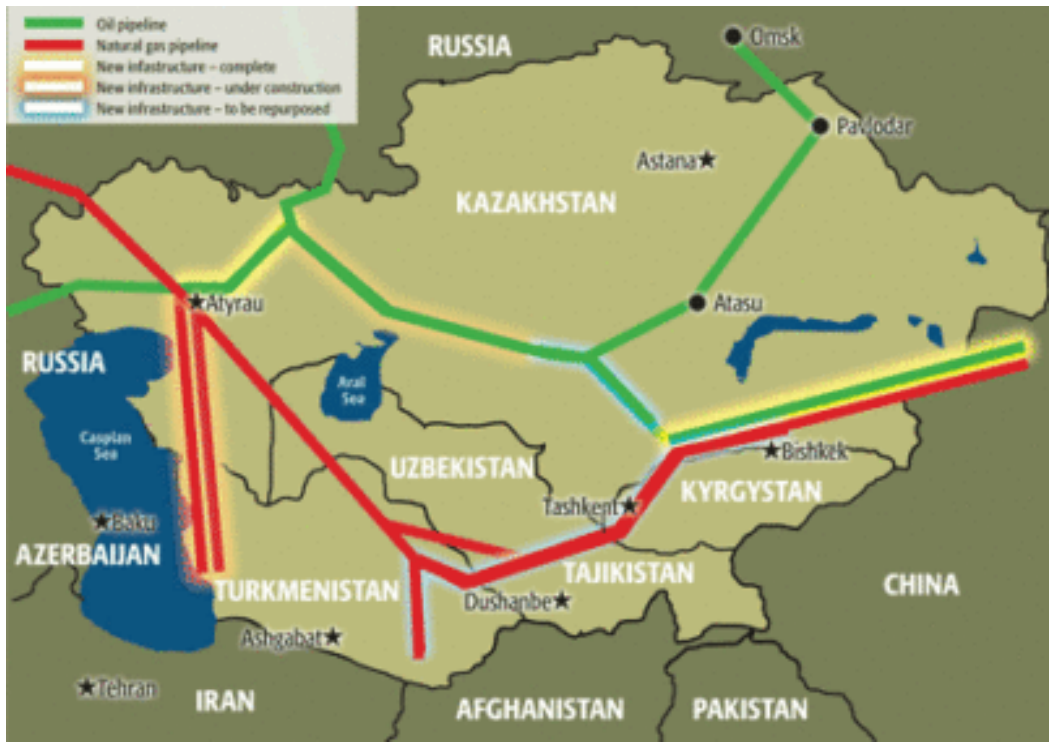

The Kazakhstan-China pipeline, which has a final capacity of 200,000 barrels of oil per day, is a symbol of China's influence in Central Asian energy resources. In addition, China reached an agreement with Turkmenistan on the gas pipeline in 2009, achieving an annual capacity of 30 billion cubic meters of Turkmen gas to China. Meanwhile, China is negotiating with Kazakhstan to buy the country's gas through the construction of a new pipeline that starts in Ishim, reaches Astana, and finally reaches Alashanko on the Chinese-Kazakh border. China National Petroleum Corporation has

${ }^{7}$ https://www.eurasianbusinessbriefing.com/wp-content/uploads/2015/02/China-Central-Asiapipelines.gif [accessed 10/08/2020] 
https://berumpun.ubb.ac.id/index.php/BRP

also signed a USD 600 million contract to extract oil from 23 small oil fields with Uzbekistan, and hopes to acquire gas in these fields.

In addition to Central Asian countries, China has managed to reach important agreements with Russia as its most important Western neighbor in the field of energy; Russia's strategic pipeline to the country is under discussion, and some have been implemented. The latest development in this area was the launch of the RussianChinese oil pipeline, which starts from the city of Escrowdino in the Amur region in the far east of Russia and reaches the city of Waking in northeastern China, in early 2011. Construction of the 1,000-kilometer pipeline, 72 kilometers of which is inside Russian territory and 927 kilometers of which is in Chin's territory, began in 2010 and was completed quickly. According to the agreement between the two countries, 15 million tons of Russian oil will be transported to China annually through this pipeline between 2011 and 2030 (Simes, 2020).

\section{5-3. Expand influence}

China has been the dominant power in Asia for centuries on its very long history, and after significant economic growth in recent decades and its gradual transformation into military and cultural potential, has significant capacity to play a role. On this basis, and in the current situation, China is clearly seeking to expand its influence in the surrounding environment by playing a leading role and shaping the developments in this environment. China is trying to play this role in the form of multilateral mechanisms. The Shanghai Cooperation Organization is a key symbol of China's efforts to play such a role, a multilateral mechanism that has long been an effective tool for achieving this goal.Generally, the expansion of influence and the role of leadership in the surrounding environment can be considered as China's long-term goal of shaping and strengthening the Shanghai Cooperation Organization.Indeed, China, like Russia, to some extend, considers the Central Asian region as part of its "backyard" or "sphere of influence" (Daily FT, 2017). However, one can assume that as Central Asia is Russia's traditional sphere of influence, Moscow does not like to share that influence with China.

\section{5-4. Efforts to create a multipolar world and counter American hegemony}

Through gaining Russian friendship (from China's point of view, Russia can prevent the expansion of the United States) in the framework of the SCO and trying to block NATO's advance to the western borders of China, indeed, Beijing would be able to counter the U.S. hegemony (Carroll, 2011:4-6). 
https://berumpun.ubb.ac.id/index.php/BRP

\section{CONCLUSION}

Through the "SCO spirit," the Shanghai organization has emerged as one of the most successful multilateral institutions not only in Eurasia but also in the glob. By development of SCO, there has been a great opportunity for its members- by forming East coalition - to cooperate with each other thorough regional integration. Therefore, the members of SCO try to make the balance of power in the world. Furthermore, development of this organization could provide more security, economic and trade opportunities, political and cultural integration for members that-it can be a motivation for more cooperation among the members.

The SCO has the potential to emerge as a serious organization capable of confronting U.S. hegemony provided China and Russia take practical steps in challenging the almost unbridled power of U.S. and its West European allies in various regions of Asia particular Central Asia. Otherwise, the SCO is destined to become another ineffective multilateral talking forum on the pattern ASEAN, OIC and so on.

The Shanghai Cooperation Organization is a Eurasian political, economic and security alliance. In terms of geographic area and population, it makes the organization the largest in the world, and one of the most powerful. With China and India, the two largest and fastest developing SCO members, plus Russia, the contributions they are making together with other members to the world economic growth and prosperity are very crucial.

Chinese foreign policy for the Eurasian region centers around regional stability and economic development; all to facilitate its 'peaceful rise' and 'harmonious world'. China further holds multilateralism at the centre of this and the SCO due to the multilateral platform that China was pinnacle in establishing, thus giving China large amounts of influence over the organisation and making it a tool for China to meet its policy ends. China's usage of the SCO has resulted in many of its foreign policy ends being reached or at least had significant progress towards them.

Generally, increased institutionalization and empowerment of the SCO is the appropriate way forward for Chinese foreign policy and "go global" notion as it would increase Beijing effectiveness.China, as the most important founder and member of the Shanghai Cooperation Organization, has so far shown that it has the will and, to some extent, the leadership skills and capacity of this organization. Beijing pursues a range of goals and interests in the process of formation and strengthening of this organization. The important point is that these goals and interests are in line with the macro strategy of this country and its foreign policy goals. In other words, the goals that China pursues in this organization are in line with the larger goals of the country in the international arena. Over time, China sees the Shanghai Cooperation Organization both as a means to promote regional security and as a vehicle to promote regional cooperation in many other areas. 
https://berumpun.ubb.ac.id/index.php/BRP

\section{ABOUT THE AUTHORS}

Enayatollah Yazdani is an Associate Professor of International Relations, Center for Middle East Studies, School of international Studies, Sun Yat-sen University, Zhuhai, China and Department of Political Sciences, University of Isfahan, Isfahan, Iran. He holds a PhD in Political Science and International Relations from the Australian National University (ANU), Canberra, Australia. He has been visitor scholar at Indiana University, Boolimington, Indiana, and University of Washington, Seattle, Washington, USA, 2003, and 2012-2013. He has published 5 books and book chapters: Globalization and the role of Islam in Central Asia, the Importance of Central Asia for the International Powers, ISIL in the Middle East, Military in the Middle East and Islamic Culture. He has published more than 150 papers in scholarly journals. He has also contributed to many international conferences and presented his papers around the wold in USA, Russia, China, UK, Australia, Iran Germany, India, Kyrgyzstan, Thailand, Turkey, and Poland.

Rizwan Hussain holds a PhD in Political Science and International Relations from the Australian National University (ANU), Canberra Australia. He is a researcher in Canberra, Australia. He is the author of Book: Pakistan And The Emergence of Islamic Militancy In Afghanistan, in addition, he has published a number of papers in scholarly journals.

\section{REFERENCES}

[1] Akimov V.(1998). Five Nation Almaty Meeting on July to Promote Friendship, Moscow ITAR-TASS (in English), June 24.

[2] Alimov R.(2018). The Shanghai Cooperation Organisation: Its role and place in the development of Eurasia. Journal of Eurasian Studies, 9(2), 114-124.

[3] Battams-Scott G.( 2019).How Effective Is the SCO as a Tool for Chinese Foreign Policy?", E-International Relations, February 26. Accessible at: https://www.eir.info/2019/02/26/how-effective-is-the-sco-as-a-tool-for-chinese-foreign-policy/.

[4] BBC Monitoring - Energy(2006).Oil begins flowing through completed KazakhChina pipeline. BBC Monitoring - Energy, June 21.

[5] Bhatty M. A.(2000).Role of the Shanghai-5. Karachi Dawn (Internet versionWWW in English), June 16.

[6] Bhaya A. G. (2019). Russia, India enhance China's trade within SCO amid tariff war.CGTN, June 15.

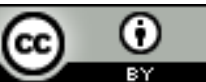


https://berumpun.ubb.ac.id/index.php/BRP

[7] Bolonina A.(2019).Security dimensions of China presence in Central Asia. Asian Focus,(108), 6.

[8] Business Reporting Desk(2020), April 16.

[9] Carroll W. E.(2011). China in the Shanghai Cooperation Organization: Hegemony, Multi-Polar Balance, or Cooperation in Central Asia. International Journal of Humanities and Social Science, 1(19), 1-8.

[10] Chung, C. P. (2006). China and the institutionalization of the Shanghai Cooperation Organization. Problems of Post-Communism, 53(5), 3-14.

[11] Daily FT (2017). China and Russia struggle to gain control over Central Asia. Daily FT [Online]. . Accessible at: http://www.ft.lk/columns/China-and-Russiastruggleto-gain-control-over-Central-Asia/4-641055.

[12] Jefferson E. M. and Turner U. (2005). What is Driving India's and Pakistan's Interest in Joining the Shanghai Cooperation Organization?. Strategic Insights, IV(8), August.

[13] Jin W. and Kong D. (2019) .Counter-Terrorism Cooperation Between China and Central Asian States in the Shanghai Cooperation Organization. China Quarterly of International Strategic Studies,5(1),65-79.

[14] Jing Y.( 2018). Strategic Role of China in Strengthening the Shanghai Cooperation Organization(SCO). Speech, Ministry of Foreign Affairs of the People's Republic of China, February 27.

[15] Fei G. (2010). The Shanghai Cooperation Organization and China's New Diplomacy. Discussion Papers in Diplomacy, Netherlands Institute of International Relations 'Clingendael', July.

[16] Feldshuh H. (2018). China Debates the Belt and Road". The Diplomat [Online] Accessible at: https://thediplomat.com/2018/09/china-debates-the-belt-and-road/

[17] Goodenough P.(2005). China, Russia Challenge US Military Presence in Central Asia. CNSNews.com International Editor, July 6. 
https://berumpun.ubb.ac.id/index.php/BRP

[18] Grace A.(2018).The Lessons China Taught Itself: Why the Shanghai Cooperation Organization Matters. China Brief Volume,18(11), June 19.

[19] HUI Z.(2019). The Central pillars of China's diplomacy. China Today, August 16.

[20] Huirong Z. and Hongwei W.(2012). China's energy policy towards the Caspian region:the case of Kazakhstan. The Newsletter,(62),Winter.

[21] Oldberg, I. (2007). The Shanghai Cooperation Organization: Powerhouse or Paper Tiger?. Swedish Defense Research Institute.

[22] Liao J. X.(2019). China's energy diplomacy towards Central Asia and the implications on its "belt and road initiative". The Pacific Review. Accessible at: https://doi.org/10.1080/09512748.2019.1705882.

[23] Liangyu. (2018). Economic Watch: SCO in closer ties with Belt and Road Initiative. XinhuaNet [Online]

Accessible

at: http://www.xinhuanet.com/english/2018-06/09/c_137241789.htm

[24] Norov V.(2019). China has a creative and constructive role at the SCO. September 29. Accessible at:http://eng.sectsco.org/news/20190929/583793.html

[25] Saksena A. R.(2014). The Shanghai Cooperation Organization and Central Asian Security. The Diplomat, July 25.

[26] Shanghai Cooperation Organization (2018), June 10.

[27] Shanghai Cooperation Organization (2020).

[28] Simes D.(2020). Coronavirus gives Russia-China gas pipeline plan a burst of energy. Nikkei Asian Review, May 27.

[29] Sutter R. G.(2016). Chinese Foreign Relations: Power and Policy Since the Cold War. Lahnman: Rowman and Littlefield.

[30] Vakulchuk R. and Indra O.(2019). China's Belt and Road Initiative through the lens of Central Asia. In Fanny M. C. and Ying-yi H.(2019).Regional Connection under the Belt and Road Initiative:The Prospects for Economic and Financial Cooperation,(eds.) , New York: Routledge, 115-133. 
[31] Weitz R. (2006). Reading the Shanghai SCO Summit. The Central Asia-Caucasus Analyst, July 12.

[32] Weitz R. (2018). The SCO and NATO Compared, China US Focus.

August 30 . Accessible at:https://www.chinausfocus.com/peace-security/the-scoand-nato-compared

[33] World Population Review, (2020).

[34] Workman D. (2020). Crude Oil Imports by Country.World's Top Exports, April 23.

[35] Yamie W. (2019). Travels to SCO countries gaining popularity in China: newspaper. XinhuaNet), July 14.

[36] Yamei W. (2020). China-Central Asia gas pipeline transports 47.9 billion cubic meters in 2019. ,XinhuaNet, January 6.

[37] Yazdani E. and Toiserkani M.(2007). The SCO and Multilateral Process in the International System. Central Asia and the Caucasus Studies, (57), 29-70.

[38]https://www.eurasianbusinessbriefing.com/wpcontent/uploads/2015/02/China-Central-Asia-pipelines.gif

[39]http://www.hktdc.com/resources/MI_Portal/Article/rp/2015/11/472180/14 47841101389_472180CentralAsianMarkets5e_472180.jpg 